\title{
Scientific Literacy Skills of Seventh Grade Junior High School (SMP Negeri) Students in North Labuhanbatu Regency
}

\author{
Parningotan Siagian ${ }^{1}$, Melva Silitonga $^{2 *}$, Ely Djulia ${ }^{2}$ \\ ${ }^{1}$ Student of Program Biologi Education, State University of Medan, Medan, Indonesia \\ ${ }^{2}$ Lecturer of Postgraduate Biology Education, State University of Medan, Medan, Indonesia
}

*Corresponding Author: Melva Silitonga, Lecturer of Postgraduate Biology Education, State University of Medan. Medan. Indonesia.Email: melvasilitonga2013@gmail.com

\begin{abstract}
This research was conducted to describe scientific literacy skills, to know the comparison of scientific literacy skills based on geography and to see the relationship of scientific attitudes on the dimensions of content, context and process of junior high school students in North Labuhanbatu Regency. Sample used was 180 students, taken by using purposive sampling technique. Data collection techniques were conducted using science literacy tests, science process skill observation sheets and scientific attitude questionnaire. The result showed that scientific literacy skills of junior high school students in North Labuhanbatu Regency was 60,3 (low). As for scientific literacy skills based on dimension, obtained value of content dimension 50,2, context 53,3, process 62,01 and science attitude 58,6. Based on geography there was no difference in scientific literacy skills of students whom live in town or village, both in low category. Furthermore, to know the relation between dimension of scientific attitude toward content dimension, context and process, correlation test and regression test was done as follow-up test. The value of $r_{\text {count }}$ relationship of scientific attitudes with content was $0.611, r_{\text {count }}$ relationship of scientific attitudes to context was 0.478 , and $r_{\text {count }}$ scientific attitude toward process was 0.882. Correlation test showed that there was a close relationship between dimensions of scientific attitude towards dimensions of content, context, and process and the correlation was positive. The results indicated that teachers, school and education authorities in regency need to make improvements in the learning process to improve student's science literacy.
\end{abstract}

Keywords: Science Literacy, Science Process Skills, Scientific Attitude

\section{INTRODUCTION}

According to PISA (OECD, 2012) science literacy is as knowledge and its use to identify questions, acquire new knowledge, explain scientific phenomena and draw conclusions based on scientific evidence. By definition, students should be involved in a process in learning. One Natural Science essences is act as a process. According to Sujana (2012) "The process of natural science or science should be directed so that students want to do something not only understand something." Thus, in learning natural science, students are asked to take an active role in learning. Indonesia is a consistent country in participating PISA test. But the achievement of Indonesian science literacy is always below international standards that have been set and even tend to decrease. According to PISA 2015, Indonesia was ranked 62 out of 70 Countries (OECD, 2016). National Science Education (NSES) which states that science literacy is a collection of knowledge and understanding of science concepts and processes owned by someone who studies science so they could participate in society's progress (Jenice \& Downey, 2013).

Low level of scientific literacy skills also found by Anggraini (2014), the research shows that scientific literacy skills of class in Solok still "below average", the percentage obtained was $27.94 \%$ $(\leq 54 \%)$. The factors which may cause this were subject matter that has never been studied, students were not accustomed to working on problems using discourse, and the learning process did not support students develop the ability of science literacy. In an ideal science learning perspective, learning activities should facilitate students to train student's science literacy skills (Utari et al, 2015). Putri (2014) said the cause of the low scientific literacy skillsstudents is that teachers are less accustomed to learning process that supports students to literate in science. UNESCO recognizes that "science literacy is essential to communicating sustainable development. Capacity building for 
communities to address environmental issues" (UNESCO, 2013). Literacy is a starting point for students to know the readiness of students in order to face the challenges that exist in society. Science literacy can be a benchmark for future career determination, even if students engage in science or not (Lin et al., 2012).

Based on the explanation about the importance of science literacy, it is necessary to know the quality of science literacy students in North Labuhanbatu regency. According to Turiman et al (2012), learners need to be equipped with 21 st century skills to overcome challenges in science and technology. The dimensions of science literacy that would be analyzed were science as content, science as context, science as process and scientific attitude. In addition, this study also used a sample of State Junior High School (SMP Negeri) that apply KTSP as a curriculum in learning. Based on preliminary analysis conducted by researchers on the students at junior high school in North Labuhanbatu Regency, through the questionnaire found 65\% said that media was rarely use in learning and so did the practicum. This was due to inadequate laboratory facilities and lack of teacher commitment in practicum activities. It is expected that the information obtained from this research will contribute and useful to know the scientific literacy skillsof seventh grade junior high school students (SMP Negeri) in North Labuhanbatu Regency. This research was done as a first step to improve the quality of education in North Labuhanbatu Regency, especially in improving student's literacy skills.

\section{MATERIALS \& METHODS}

\subsection{Research Place, Population and Sample}

This research was conducted in State Junior High School (SMP Negeri) in North Labuhanbatu Regency, North Sumatera Province. This research was conducted from December 2016 until July 2017. The population in this research was all seventh grade junior high school students in North Labuhanbatu Regency which 2395 students in total and spread in 26 junior high school. The sample used was 180 students, grouped into 6 classes from 6 schools and 6 districts. Sampling technique was taken by purposive sampling technique.

\subsection{Research Design}

This research was a descriptive research. The design, according to Sukardi (2003), is to make description systematically, factual, and accurate about scientific literacy skills of junior high school student of North Labuhanbatu Regency. The research did not provide treatment, manipulation or alteration to the independent variables, but describes a condition as it is (Sukmadinata, 2012). Scientific literacy skills was known from the results of the science literacy test and then percentage of correct answers was analyzed according to the indicator adapted Gormally et al. (2012).

\subsection{Research Instrument \& Data AnalisisTechnique}

The instruments used in this research were science literacy test on content and context dimension, observation sheet of science process skill and student's scientific attitude questionnaire. Research data was analyzed using Microsoft Excel for tabulation of values. Furthermore, the prerequisite test, normality test of Kolmogorov Smirnov and homogeneity test with Levene's test was done. Man Whitney test, correlation test and regression test were also done as follow up tests. All data were analyzed using the IBM SPSS Statistics 22 program.

\section{RESULTS \& DISCUSSION}

\subsection{Research Result}

Student's scientific literacy skillsin this study were analyzed on the dimensions of science as the content, context, process/scientific skills and scientific attitude. Generally, scientific literacy skills of the seventh grade students was in the low category of 56,9 with an average score was 56.1. Furthermore, the scientific literacy skillsbased on the geographical value of the school was 60.9 in the town and 59.8 in Village. The results were same in town and village for each dimension. The value of science literacy skills is shown in the Diagram 3.1. It can be seen that the students in town got a higher average score compared to students in village, although the comparison was not always different significantly. But in the process dimensions, students in Village get higher score compared 
to students in town. Difference average score was also seen in content dimension, where students in the town obtained an average score of 53.3 with an individual average score of 8 . While the value of the content dimensions of students in the Village was 47.3 with an average score of 7,1 . While the value of the scientific attitude dimensions of students in town and in the village did not differ significantly, with the average value of 76.1 and the average score 76 (in town) and average 75.4 with average score average 75 (in village). For more details see figure3.1.

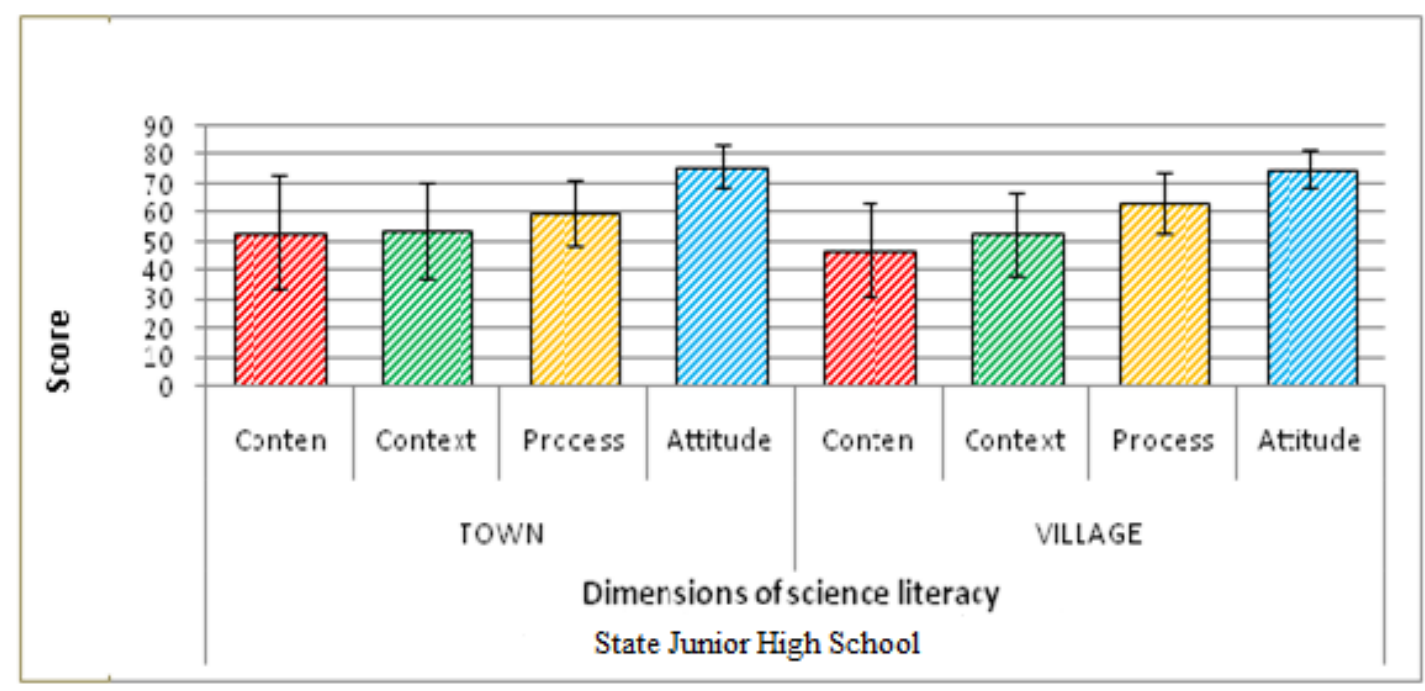

Figure3.1. Scientific Literacy Skills of seventh grade students based on geographical location

Furthermore, this study was also comparing the ability of science literacy of high school students on geography. The statistical analysis for scientific literacy skills data of students in this research can be seen in Table.3.1.

Table.3.1. Data Analysis of Scientific Literacy Skills of seventh grade students based on geographical location

\begin{tabular}{|l|l|l|l|l|}
\hline No & Test & Test type & Result & Test Type \\
\hline 1 & Normality & Kolmogorov Simirnov & Sig. 0,39>0,05 & Data Normal \\
\hline 2 & Homogeneity & Levene Statistics & Sig. 0,035<0,05 & Data Heterogeneous \\
\hline 3 & Difference Test of & Man Whiteney & $\begin{array}{l}\text { Asymp.Sig.(2-tailed) } 0.18> \\
0.05\end{array}$ & $\mathrm{H}_{0}$ was accepted \\
& Average Value & & & \\
\hline
\end{tabular}

Result of normality test of scientific literacy skills data of students in city and village had significance value equal to $0,39>0,05$, so it was concluded that scientific literacy skills junior high school students in Town and Village of North Labuhanbatu was normally distributed. Furthermore, the homogeneity test results showed the significance value was $0.035<0.05$, means scientific literacy skills students in town and in the village of Labuhanbatu Regency had a different variant (heterogeneous). Because of data was heterogeneous, then Man Whiteney test was done, the value of Asymp.Sig (2-tailed) was $0,18>0,05$, it means that Ho was accepted, or there was no difference between literacy skill of grade VII students of junior high school in Town with students in the Village of North Labuhanbatu. The proof of the analysis could be seen from the science literacy score of the seventh grade students of junior high school in Town 60,9 (low), while 59.8 (low) in village. Furthermore, to know the relationship between the dimensions of scientific attitudes toward the content dimension, the context and the process, correlation test and regression test was done as a follow-up test. The value of $r$ count obtained from the relationship of scientific attitude with content $(0.611)$, with regression equation $\mathrm{Y}=$ $-17,092+1,15 X\left(R^{2}=0,373\right), r$ count relationship of scientific attitude to context $(0,478)$, and $r$ count scientific attitude to process $(0,882)$. The correlation test indicated that therewas a close relationship between the dimensions of scientific attitude toward content dimension, context, and process and this correlation was positive. The relationship of student's scientific attitude toward content dimension can be seen in Figure.3.2. below. 
Scientific Literacy Skills of Seventh Grade Junior High School (SMP Negeri) Students in North Labuhanbatu Regency

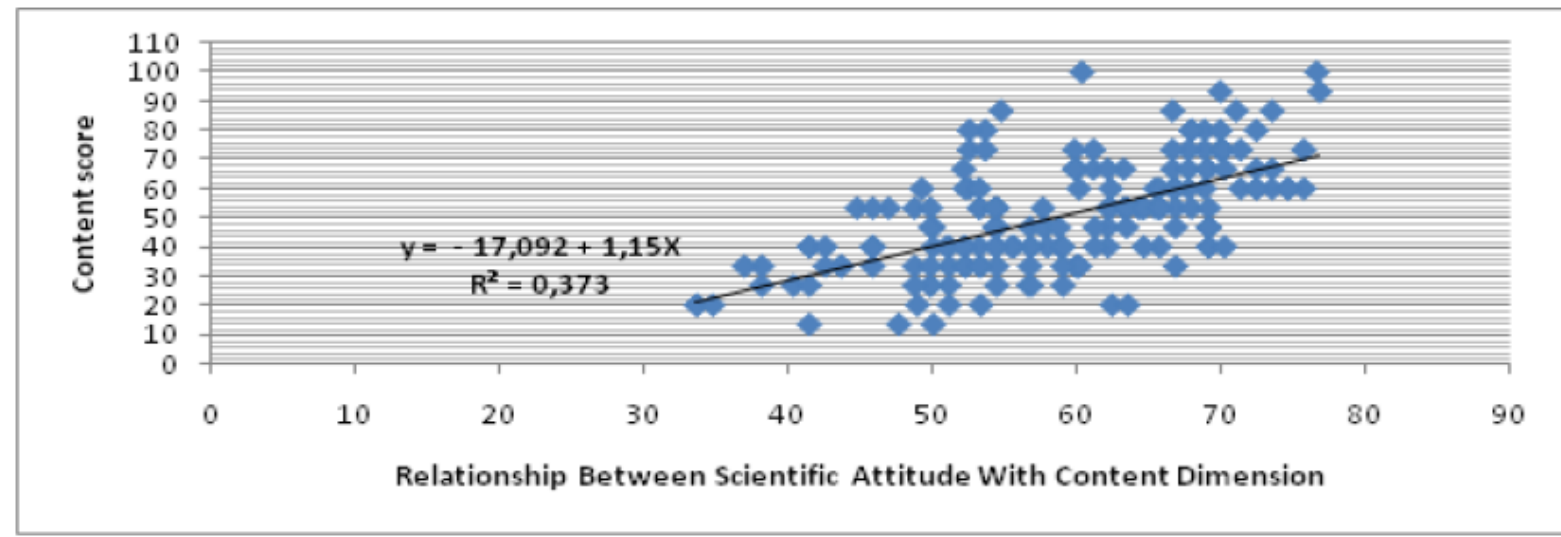

Figure3.2. Relationship between Scientific Attitude with Content Dimension of Junior High School students in North Labuhanbatu

Likewise, the relationship of student's scientific attitude toward context dimension, regression test results obtained $r$ count was 0,478 , with regression equation $Y=7,985+0,774 X\left(R^{2}=0,2286\right)$. The relationship of student's scientific attitude to context dimension can be seen in Figure 3.3. below

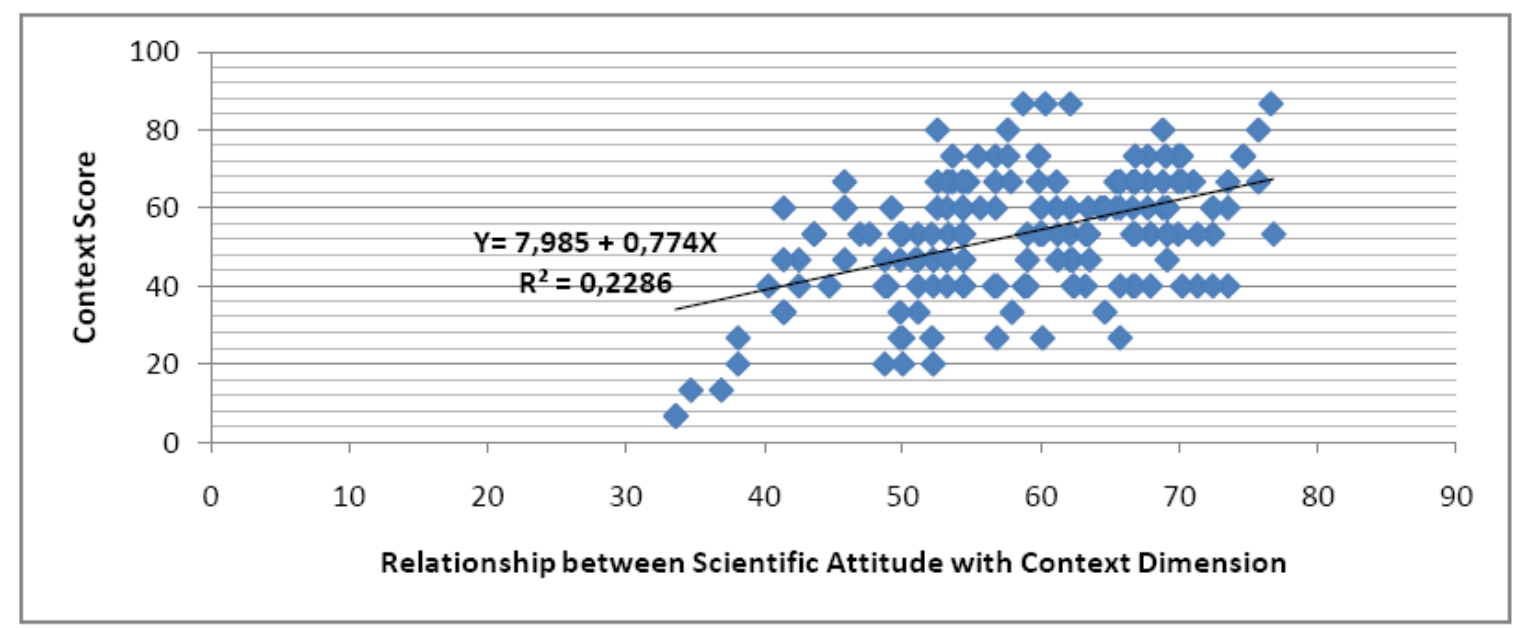

Figure3.3. Relationship between Scientific Attitude with Context Dimension of Junior High School students in North Labuhanbatu

The correlation between students' scientific attitude toward process dimension, correlation test result obtained dimension $r$ count process was 0,882 with regression equation $\mathrm{Y}=2,283+1,019 \mathrm{X}\left(\mathrm{R}^{2}=\right.$ $0,778)$. The relationship of student's scientific attitude toward process dimension can be seen in Figure 3.4 below

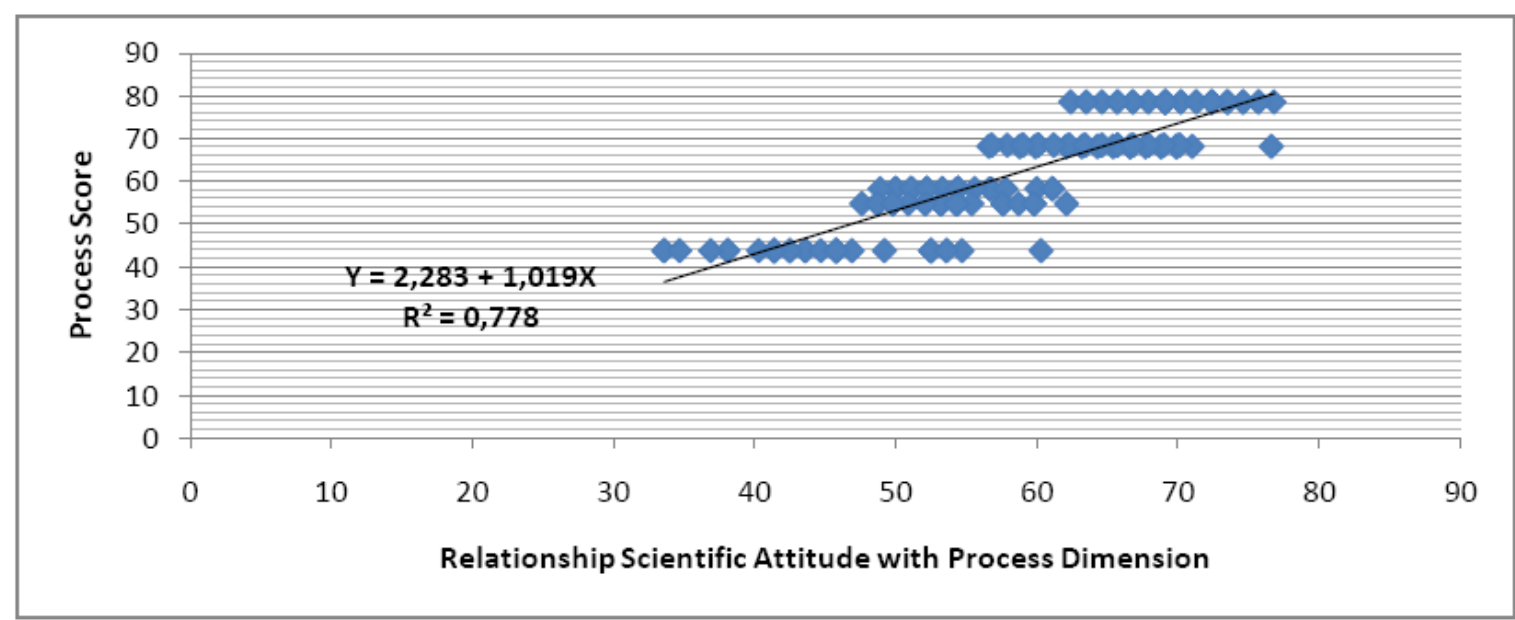

Figiure3.4. Relationship Scientific Attitude with Process Dimensionof Junior High School students in North Labuhanbatu 


\subsection{Discussion}

\subsubsection{Students Scientific Literacy Skills According to Literacy Dimension}

Based on the results of the research, it was found that the score of scientific literacy skills of seventh grade junior high students in North Labuhanbatu Regency was categorized as low. These results generally show that most students do not yet have the characteristics of an individual who is literate on science. It was found that from the results of the research, the student's science literacy skills was still not in accordance with the theory of science literacy according to PISA (OECD, 2012) where science literacy is as knowledge and its use to identify questions, gain new knowledge, explain phenomenon scientific and drawing conclusions based on scientific evidence. So it is necessary to apply science-based learning literacy. Udompong (2014) found that the application of learning with a scientific approach can build a positive attitude toward science. Literacy of science is very important mastered by a learner because it can determine the future of a student. A person who has literacy in science will be able to read, understand, and have responsibility in handling daily life issues (Keefe, 2011 \& Claugh, 2013). This is in accordance with statement of Lederman et al (2013) that student's science literacy is related to student's ability and readiness to take decisions in action.

The low literacy of science in the seventh grade of Junior High School of North LabuhanbatuRegency occur is suspected because of students unfamiliarity in learning by science literacy-based learning and also not yet accustomed in discussing science literacy questions. Contextual problems in learning should be explored to train student's science literacy (Anjarsari, 2014). In addition, students should be motivated to apply their concepts in solving problems in both personal and global contexts. So it becomes something new for students when tested using science-based literacy questions. Angraini (2014) states many things that cause the science literacy of students to be low, such as lesson material that has not been studied, students who are not accustomed to working on problems that use discourse, and learning processes that are less supportive of students in developing the ability of science literacy.

\subsubsection{Students Scientific Literacy Skills According to Geograpical location}

Based on geographical location, scientific literacy skills of grade VII students in Town was 60,9 (low), and science literacy score of students in village was 59,8 (low). This result proved that scientific literacy skillsof grade VII students based on geographic location in North Labuhanbatu Regency had no difference. This may indicated by factors of economic status, occupation and student activity after school at home. North Labuhanbatu regency is a district whose majority of the population lives from agricultural products and plantations. So the majority of the student's parents work was farmers. Based on the researcher's experience, student's habits after school were helping their working parents and some others were playing. Slameto (2013) says that the ability of science literacy is influenced by internal factors and external factors. Internal factors include student interest and student readiness to learn. The external factor is the work of the parents. The interest of students to study at home is still very low because it is influenced by the surrounding environment. Kesuma (2012) also concluded that the socio-economic background of the family is significantly related to the students' science literacy. The socio-economic background of the family includes the educational background of the student's parents.

\subsubsection{Relationship of Science Attitude on Content, Context, and Process Dimension}

According to correlation test, student's scientific attitude toward content dimension, context dimension, and process dimension were categorized had strong correlation. The research results obtained a positive value $r$ count, which means the correlation between two or more variables that run in the same direction or in line. In this study, it could be defined that the higher the value of science literacy on the dimensions of content, context, and process then the higher scientific attitude of students. The results of this study are in line with the results of research conducted by Veloo et al. (2013) which states that the scientific attitude has a positive influence on conceptual understanding because the student's scientific attitude is able to encourage them to be more interested and involved in science learning,therefore student's concept comprehension becomes better.

Scientific attitude is very meaningful in social interaction, science and technology. If the scientific attitude has been formed in the student's selves, then good attitude will follow, whether in carrying 
out investigations or interact with the community. Indirectly, scientific attitudes in the learning process of science can solve the problems of children's morality in this nation. If the student does not have scientific attitude in carrying out the experiment, it will negatively affect the product of science or technology produced. According to Diana et al., (2015), in order to increase student's scientific literacy skills, the teachers are encouraged to start introducing and learning materials using various strategies of science literacy, such as to teach the material through experiments that can stimulate higher-order thinking and contextual oriented.

\section{CONCLUSION}

Based on the results and discussion in this study it can be concluded that the ability scientific literacy skills of junior high school students in North Labuhanbatu Regency based on science literacy dimension was in low category. Furthermore, based on geographical location, there was no difference scientific literacy skills of junior high school students in town with students in villages of North Labuhanbatu regency, which the score value in Town was 60.9 (low), and in Village was 59,8 (low). And the relationship between student's scientific attitude with content dimension, context dimension and process dimension are positive correlation and categorized into strong category.

\section{REFERENCES}

Anggraini, G. 2014. Analisis Kemampuan Literasi Sains Siswa SMA Kelas X di Kota Solok, Prosiding Mathematic and Science Forum 2014.

Anjarsari, P. 2014. Literasi Sains dalam Kurikulum danPembelajaran IPA SMP. Yogyakarta: UniversitasNegeri Yogyakarta.

Diana, S., Arif, R., Euis, S. R. 2015. Profil Kemampuan Literasi Sains Siswa SMA Berdasarkan Instrumen Scientific Literacy Assesments (SLA). SeminarNasional XII Pendidikan Biologi FKIPUNS 201.

Gormally, C., Peggy B., \& Mary L. 2012. Developing a Test of ScientificLiteracy Skills (TOLS): Measuring Undergraduates "Evaluation of Scientiffic" Information and Arguments. CBE-Life Sciences Education, 11 (2012), 364-377.

Jenice G. M \& Downey L. 2013. Your Science Classroom. USA : SAGE Publication,Ltd

Keefe, E.B. and Copeland, S.R. 2013. What is literacy? The power of a definition. Research and Practice forPersons with Severe Disabilities Vol 36(3-4) 92-99.

Kesuma, Dharma, dkk. 2012. Pendidikan karakter (kajian teori dan praktik di sekolah). PT Remaja Rosdakarya.

Lederman, N.G., Lederman, J.S., \& Antink, A. 2013. Nature of Science and Scientific Inquiry as Contexts for the Learning of Science and Achievement of Scientific Literacy. International Journal of Education in Mathematics, Science and Technology, Volume 1, Number 3, July 2013, 138-147 ISSN: 2147-611X. Download 5 Oktober 2014, from www.ijemst.com.

Lin, H.S., Hong, Z.R. \& Huan, T.C. 2012. The Role of Emotional Tractors in Building Public Scientific Literacy And Engagement with Science. International Journal of Science Education, Vol.34, No.1, 1 Januari 2012, Pp. 25-42.

OECD. 2012. PISA2012Results in Focus What 15-year-olds know and what they can do with what they knot. http://www.oecd.org pisa/keyfindings/pisa-2012-resultsoverview.Pdf.

OECD (2016) PISA 2015, PISA Results in Focus. www.oecd.org/pisa/pisa-2015-results-in-focus.pdf.

Putri, A. E. 2014. Kemampuan Penalaran Siswa Kelas X IPA SMA Terkait dengan Konsep Biologi (Online). Diakses pada tanggal 12 November2015

Slameto. 2013. Belajar dan Faktor-Faktor yang Mempengaruhi. Rineka Cipta. Jakarta.

Sujana, A. 2012. Pendidikan IPA teori dan praktik. Sumedang: Rizal Nur.

Sukardi, 2003. Metodologi Penelitian Pendidikan Kompetensi dan Prakteknya. Jakarta: Bumi Aksara

Sukmadinata. 2012. Metode Penelitian Pendidikan. Bandung: PT. Remaja Rosdakarya

Turiman P.,Omar J., Daud A M., \& Osman K. 2012. Fostering the 21st Century Skills through Scientific Literacy and Science Process Skills. Procedia - Social and Behavioral Sciences 59 (2012) 110-116. (Online), (http://www.sciencedirect.com/ science/article/pii/S187704281203 6944, diakses 20 oktober 2015)

Udompong, L, dan Suwimon Wongwanich 2014, 'Diagnosis of the scientific literacy characteristic of primary students', Procedia Sosial and Behavioral Science, vol. 116, pp. 5091-5096.

UNESCO. 2013. United Nations Literacy decade (2003-2012). New York: UN. 
Utari, S., Karim, S, Setiawan, A, Nugraha, MG, Saepuzaman, D, \& Prima, EC. 2015. Designing Science Learning For Training Students' Science Literacies At Junior High School level. International Conference on Mathematics, Science, and Education 2015.

Veloo, A., Selvan P., \& R.Vikneswary. 2013. Inquiry Based Instruction, Students' Attitudes and Teachers' Support Towards Science Achievement in Rural Primary Schools. Procedia Social and Behavioral Sciences. Vol. 93, 65-69

\section{AUTHORS' BIOGRAPHY}

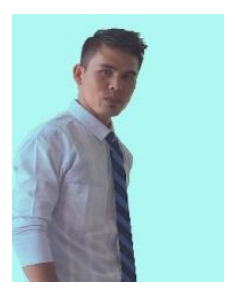

Parningotan Siagian, S.Pd, is a Biology Education postgraduate student at Postgraduate Programe of Universitas Negeri Medan (Medan State University), Medan, North Sumatera, Post code 20221, Indonesia. He obtained him Sarjana Degree (S1) in Biology Education from Yayasan Universitas Labuhanbatu he obtaining Master Programe in Biology Education on Universitas Negeri Medan. Email: siagian.parningotan@gmail.com

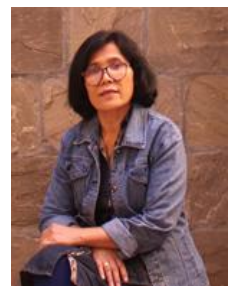

Dr. Melva Silitonga, M.S, is a lecturer at Graduate and Postgraduate Programe of Universitas Negeri Medan (Medan State University), Medan, North Sumatera, Post code 20221, Indonesia. She obtained her Sarjana Degree (S1) in Biology Education from IKIP Medan, herMagister degree (S2) of science in biology from Bogor Agriculture Institute (IPB Bogor) and her Doctor Degree (S3) in Biology Program from Universitas Sumatera Utara (North Sumatera University) Medan.

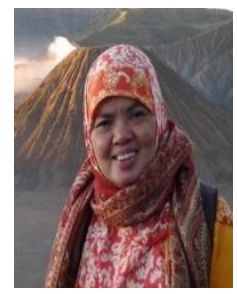

Dr. Ely Djulia, M.Pd, is a lecturer at Graduate and Postgraduate Programe of Universitas Negeri Medan (Medan State University), Medan, North Sumatera, Post code 20221, Indonesia. She obtained her Sarjana Degree (S1) in Nature Science Education from IKIP Bandung, her Master Degree (S2) in Nature Science Education from IKIP Bandung, Her Doctor Degree (S3) in Nature Science Education from UPI Bandung.

Citation: Parningotan Siagian et al. " Scientific Literacy Skills of Seventh Grade Junior High School (SMP Negeri) Students in North Labuhanbatu Regency " International Journal of Humanities Social Sciences and Education (IJHSSE), vol 4, no. 11, 2017, pp. 176-182. doi: http://dx.doi.org/10.20431/2349-0381.0411021.

Copyright: (C) 2017 Authors. This is an open-access article distributed under the terms of the Creative Commons Attribution License, which permits unrestricted use, distribution, and reproduction in any medium, provided the original author and source are credited. 